\title{
Control of volunteer corn with rates of post-emergent ACCase inhibitors applied at different phenological stages
}

Bárbara Suellen de Almeida Santos, Abílio Felipe Oliveira Lopes, Guilherme Mendes Pio de Oliveira, Giliardi Dalazen

Universidade Estadual de Londrina - UEL, Londrina, PR. E-mail: giliardidalazen@gmail.com

\begin{abstract}
The occurrence of volunteer corn (Zea mays L.) has been common in Brazilian crops due to the adoption of a succession of soybean (Glycine max (L.) Merrill) and corn resistant to glyphosate. The aim of this work was to evaluate the control of volunteer corn using different rates of acetyl-CoA carboxylase (ACCase) inhibitors herbicides at different phenological stages. The experiment was carried out in a greenhouse in a completely randomized design. The experiment was organized in a factorial scheme $(3 \times 7 \times 2)$ with three herbicides (clethodim, quizalofop- $P$-tefuryl and clethodim + quizalofop- $P$-ethyl) applied at seven rates $[0 ; 25 ; 50 ; 100$; 200; 400 and $800 \mathrm{~mL}$ of commercial product (C.P.) ha ${ }^{-1}$ ], and at two corn phenological stages (V3 and V6). Visual control (\%) assessments were carried out at 14, 21 and 28 days after application of treatments (DAT) and shoot dry mass (SDM) at 28 DAT. The data were submitted to analysis of variance and to complementary analysis by logistic regression adjustment. For all herbicides, the control of volunteer corn was greater at V3 stage, requiring lower rates compared to V6. Complete visual control of volunteer corn plants at V3 was obtained with rates of $25 \mathrm{~mL} \mathrm{C.P.} \mathrm{ha-}{ }^{-1}$ for all herbicides evaluated, corresponding to 6, 3 and $6+3 \mathrm{~g}$ a.i. ha $^{-1}$ of clethodim, quizalofop- $P$-tefuryl and clethodim + quizalofop- $P$-ethyl, respectively. For V6 application, $400 \mathrm{~mL} \mathrm{C.P.} \mathrm{ha}{ }^{-1}$ of clethodim (equivalent to $96 \mathrm{~g}$ a.i. ha ${ }^{-1}$ ) and $100 \mathrm{~mL} \mathrm{C.P.} \mathrm{ha}{ }^{-1}$ of quizalofop- $P$-tefuryl (equivalent to $12 \mathrm{~g}$ a.i. ha $^{-1}$ ) and clethodim + quizalofop- $P$-ethyl (equivalent to $24+12 \mathrm{~g}$ a.i. ha $^{-1}$ ) were necessary to achieve $100 \%$ of plant mortality. Thus, the efficiency of clethodim was more dependent on the stage of application compared to others herbicides, requiring higher rates to achieve complete control of volunteer corn at V6.
\end{abstract}

Keywords: clethodim; graminicides; quizalofop-P; Zea mays; weed control.

\section{Controle de milho voluntário com doses de inibidores da ACCase pós-emergentes aplicados em diferentes estádios fenológicos}

\section{Resumo}

A ocorrência de milho (Zea mays L.) voluntário tem sido comum nas lavouras brasileiras devido à adoção da sucessão de soja (Glycine max (L.) Merrill) e milho resistentes ao glyphosate. O objetivo deste trabalho foi avaliar o controle de milho voluntário com diferentes doses de herbicidas inibidores da acetil-CoA carboxilase (ACCase) em diferentes estádios fenológicos. O experimento foi conduzido em casa de vegetação, em delineamento inteiramente casualizado. $O$ experimento foi organizado em esquema fatorial (3×7x2), sendo três herbicidas (clethodim, quizalofop- $P$-tefuryl e clethodim + quizalofop- $P$-ethyl), aplicados em sete doses $\left[0 ; 25 ; 50 ; 100 ; 200 ; 400\right.$ e $800 \mathrm{~mL}$ do produto comercial (P.C.) ha- ${ }^{-1}$ ], em dois estádios fenológicos do milho (V3 e V6). Foram avaliados o controle aos 14, 21 e 28 dias após a aplicação dos tratamentos (DAT) e a massa seca da parte aérea (MSPA) aos 28 DAT. Os dados foram submetidos à análise de variância e à análise complementar por meio do ajuste de regressões logísticas. Para todos os herbicidas, o controle de milho voluntário foi maior em V3, demandando doses menores em comparação ao estádio V6. O controle total de plantas de milho voluntário em V3 foi obtido com doses de $25 \mathrm{~mL}$ P.C. ha ${ }^{1}$ para todos os herbicidas avaliados, correspondendo a 3,6 e $3+6 \mathrm{~g}$ i.a. ha ${ }^{-1}$ de clethodim, quizalofop- $P$ tefuryl e clethodim + quizalofop- $P$-ethyl, respectivamente. Para a aplicação em V6, foram necessários 400 $\mathrm{mL}$ P.C. ha ${ }^{-1}$ de clethodim (equivalente a $96 \mathrm{~g}$ i.a. ha $^{-1}$ ) e $100 \mathrm{~mL}$ P.C. ha ${ }^{-1}$ de quizalofop-P-tefuryl 
(equivalente a $12 \mathrm{~g}$ i.a. $\mathrm{ha}^{-1}$ ) e clethodim + quizalofop-P-ethyl (equivalente a $24+12 \mathrm{~g}$ i.a. ha ${ }^{-1}$ ) para se atingir $100 \%$ de controle. Assim, a eficiência do clethodim foi mais dependente do estádio fenológico de aplicação em comparação aos demais herbicidas, requerendo doses maiores para atingir o controle total de milho voluntário em V6.

Palavras-chave: Clethodim; controle de plantas daninhas; graminicidas; quizalofop-P; Zea mays.

\section{Introduction}

The introduction of Roundup Ready ${ }^{\circledR}$ (RR) corn (Zea mays L.) technology on the market has brought benefits to crop management in relation to weed control because it allows the use of glyphosate in post-emergence, which was quickly adopted by most brazilian farmers (ALBRECHT et al., 2014). However, the intensification of these hybrids adoption in the succession system with RR soybean (Glycine max (L.) Merrill) also favored the occurrence of volunteer RR corn plants into soybean crops (MARCA et al., 2015).

Volunteer corn plants originate from the loss of grains during harvest. These losses can occur in the form of individual grains, which originate individual plants, or in the form of whole ears or ear fragments containing several grains, which give rise to several corn plants in the same point, called clump (PIASECKI et al., 2018). About $1.34 \%$ of the grains produced by corn are lost during the harvest, which will germinate and cause interference in the next crop (TABILE et al., 2008).

Corn is a plant with C4 metabolism, highly competitive for water, nutrients and light compared to soybean, which has C3 metabolism (SAGE, 2004). Thus, even at low densities, volunteer corn can significantly reduce soybean yield through the reduction in the number of pods per plant, grains per pod and average grain mass (SILVA et al., 2008). As they contain more plants clustered, ear clumps can cause greater losses in soybean compared to individual plants (LÓPEZ-OVEJERO et al., 2016; PIASECKI et al., 2018). Soybean grain yield was reduced in $46 \%$ and $100 \%$ at densities of 0.5 and 12 clumps $\mathrm{m}^{-2}$, respectively, while the losses caused by the respective densities of individual plants were $22 \%$ and $89.6 \%$ (PIASECKI; RIZZARDI, 2016). In addition to the competition, the presence of volunteer corn in soybean affects harvest operations, increases the impurity and moisture of soybean grains and serves as hosts for pests and diseases (CHAHAL; JHALA, 2015).
Among the alternatives to control volunteer $R R$ corn in soybean crops, the application of acetyl-CoA carboxylase (ACCase) inhibitors in post-emergence is predominant (LÓPEZ-OVEJERO et al., 2016). ACCase is a key enzyme in the production of fatty acids in plants (COBB; READE, 2010). These herbicides are divided into three chemical groups: cyclohexanediones (DIMs), aryloxyphenoxypropanoates (FOPs) and phenylpyrazolines (DENs), the first two of which are recommended for the control of poaceae in soybean crops (COBB; READE, 2010; AGROFIT, 2020). For DIMs, commercial products based on clethodim or sethoxydim are the most used. For the chemical group of FOPs, quizalofop- $P$-tefuryl and haloxyfop-P-methyl are widely known by producers. In addition to the availability of these isolated products, industry has commercialized mixtures of DIMs with FOPs for use in soybean crops, such as clethodim + quizalofop- $P$-ethyl and clethodim + haloxyfop-P-methyl (AGROFIT, 2020).

The efficiency of these herbicides on the control of volunteer corn can be altered due to several factors, such as rate, mixture with other herbicides, hybrid corn, environmental conditions and plant growth stage, the latter being one of the most determining factors (MACIEL et al., 2013; CARVALHO et al., 2019). In general, applications in early growth stages of corn result in greater efficiency, because young plants have a greater capacity for absorption and translocation of herbicides, due to the smaller leaf area and cuticle thickness (BLAKER; GREYSON, 1988; MARQUARDT; JOHNSON, 2013). However, the herbicides used can also be decisive in the control, and evaluations of new mixtures such as those recently available on the market should be conducted. Therefore, the objective of this work was to evaluate the control of volunteer RR corn in response to ACCase inhibitors applied at different phenological stages. 
Material and Methods

\section{Experimental design and treatments}

The experiment was conducted in a greenhouse located at the Center for Agricultural Sciences of the State University of Londrina (UEL), Londrina- PR, from September 2018 to February 2019, at natural conditions of light and temperature and periodic irrigation, keeping the soil close to field capacity. The experiment was carried out in a completely randomized design, and the treatments were organized in factorial $(3 \times 7 \times 2)$ with three replications. The experiment was conducted in two experimental runs. The herbicides (factor A) used were clethodim (Select 240 EC, $0.24 \mathrm{~kg} \mathrm{~L}^{-1}$, UPL), quizalofop-Ptefuryl (Panther $120 \mathrm{EC}, 0.12 \mathrm{~kg} \mathrm{~L}^{-1}$, UPL) and clethodim + quizalofop-P-ethyl (Kroll, $0.24 \mathrm{~kg} \mathrm{~L}^{-1}$ of clethodim $+0.12 \mathrm{~kg} \mathrm{~L}^{-1}$ of quizalofop-P-ethyl, UPL). Each herbicide was applied at rates (factor B) of zero, 25; 50; 100; 200; 400 and $800 \mathrm{~mL}$ of the commercial product (C.P.) ha ${ }^{-1}$. According to the manufacturers, the recommended rates for the control of volunteer corn are: 72 to $108 \mathrm{~g}$ a.i. $\mathrm{ha}^{-1}$ for clethodim (equivalent to 300 to $450 \mathrm{~mL}$ C.P. ha ${ }^{-1}$ ); 36 to $48 \mathrm{~g}$ a.i. ha $^{-1}$ for quizalofop-Pethyl (equivalent to 300 to $400 \mathrm{~mL}$ C.P. ha ${ }^{-1}$ ); and 72 to $96 \mathrm{~g}$ a.i. ha ${ }^{-1}+36$ to $48 \mathrm{~g}$ a.i. ha ${ }^{-1}$ for clethodim + quizalofop-P-tefuryl (equivalent to 300 to $400 \mathrm{~mL}$ C.P. ha ${ }^{-1}$ ). Applications were carried out at two phenological stages of the corn (factor C), at V3 and V6 stages (FANCELLI; DOURADO-NETO, 1997).

\section{Plant material}

The genetic material used was the hybrid corn Dekalb 265-Pro3, of super-early cycle, widely used in the second harvest of corn in Brazil. Six seeds were sown per $1 \mathrm{~L}$ pot containing a mixture of fine sand and oxysoil (1:1), previously fertilized with NPK 05-20-20 fertilizer at $300 \mathrm{~kg} \mathrm{ha}^{-1}$. One week after sowing, thinning was carried out keeping three homogeneous plants per pot. To obtain the two stages of application, the operation was repeated when the first batch of plants had three developed leaves (phenological stage V3). Thus, on the day of application there were corn plants at stages V3 and V6.

\section{Treatment application}

Herbicides application was carried out with a pressurized backpack sprayer $\left(\mathrm{CO}_{2}\right)$ calibrated to deliver $200 \mathrm{~L} \mathrm{ha}^{-1}$ using two TJ11002 nozzles spaced $0.5 \mathrm{~m}$. The application was performed at 1 $\mathrm{m} \mathrm{s}^{-1}$ and $207 \mathrm{kPa}$, keeping the nozzles at $0.5 \mathrm{~m}$ in relation to the plant canopy. As recommended by the herbicide manufacturer, Lanzar ${ }^{\circledR}$ (UPL) adjuvant $(0.5 \% \mathrm{v} / \mathrm{v})$ was added to the spray solution. During the application, the conditions of temperature, wind speed and relative humidity were adequate.

\section{Evaluations and data analysis}

The control of volunteer corn plants was evaluated at 14, 21 and 28 days after the application of treatments (DAT) using a percentage scale from zero to 100 , with zero the absence of control and $100 \%$ total control. At 28 DAT, plants shoot dry mass (SDM) were measured. For this, the three plants of each experimental unit were cut close to the ground and packed in paper bags. Then the samples were placed in an oven with air circulation at a temperature of $65{ }^{\circ} \mathrm{C}$ until reached constant mass. The samples were weighed on an analytical scale and the values were converted to percentage of SDM in relation to the respective untreated controls according to the stage of application.

The data were submitted to analysis of variance with the support of the $R$ software (version 3.5.3) in RStudio package (R CORE TEAM, 2019). After the significance was verified, complementary analyzes were performed for qualitative treatments (herbicides and application stages) using the Tukey means comparison test ( $p<0.05)$, and for quantitative treatments (herbicide rates), the threeparameter logistic regression was adjusted, according to Equation 1.

$$
y=a / 1+\left(x / x_{0}\right)^{b} \quad \text { Equation } 1
$$

\section{Where:}

$y=$ the percentage of control or SDM;

$\mathrm{a}=$ the difference between the maximum and minimum points on the curve;

$x=$ the herbicide rate (in $\mathrm{mL}$ C.P. $\mathrm{ha}^{-1}$ ) that generates the y control;

$\mathrm{x}_{0}=$ the herbicide rate (in $\mathrm{mL} \mathrm{C.P.} \mathrm{ha}^{-1}$ ) that causes $50 \%$ of the control or reduction of SDM obtained.

From the values of $x_{0}$, the values of $C_{50}$ (rate that causes $50 \%$ control) and $\mathrm{GR}_{50}$ (rate that reduces SDM by $50 \%$ ) were estimated, by 
replacing the $y$ in the equation with 50 (RITZ et al., 2015). From these parameters, the tolerance factors (TF) were calculated for each herbicide obtained by dividing $\mathrm{C}_{50}$ at $\mathrm{V} 6$ by $\mathrm{C}_{50}$ at V3. The same was done for the $\mathrm{GR}_{50}$.

\section{Results and Discussion}

The joint analysis showed that there were no differences between the repetitions of the experiment. Therefore, the averages of the two evaluation periods were used for each treatment. Control at 14 days was greater in corn plants at stage V3 compared to V6 for all herbicides and rates evaluated (Figure 1). When applied at V3, the herbicides clethodim and quizalofop- $P$-tefuryl provided control greater than $80 \%$ at $100 \mathrm{~mL}$ C.P. $\mathrm{ha}^{-1}$ (Figures $1 \mathrm{~A}$ and $1 \mathrm{~B}$ ). For the herbicide clethodim + quizalofop-P-ethyl, at the same application stage, the control was greater than 90\% from the lowest rate evaluated $(25 \mathrm{~mL}$ C.P. $\mathrm{ha}^{-1}$ ) (Figure 1C). At V6 stage all herbicides provided low control, even at the highest rates tested $\left(800 \mathrm{~mL}\right.$ C.P. ha $\left.{ }^{-1}\right)$. Clethodim and quizalofop-P-tefuryl applied at $800 \mathrm{~mL}$ C.P. $\mathrm{ha}^{-1}$ had less than $45 \%$ control on V 6 plants, while for the mixture of clethodim + quizalofop- $P$-ethyl applied at the same rate the control reached $60 \%$. Thus, it was observed that at 14 DAT, the application of graminicides at $\mathrm{V} 6$ had higher $\mathrm{C}_{50}$ values compared to the values obtained for the V3 stage (Table 1).

Figure 1. Control of volunteer RR corn at 14 DAT in response to the application of rates of clethodim (A), quizalofop-P-tefuryl (B) and clethodim + quizalofop-P-ethyl (C) at V3 and V6 stages. * indicates significance by the Tukey test $(p<0.05)$ between stages within the same herbicide rate.

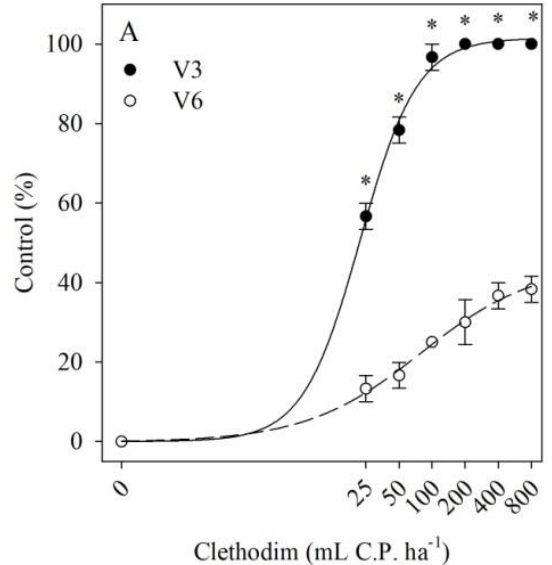

Clethodim (mL C.P. ha $\left.{ }^{-1}\right)$

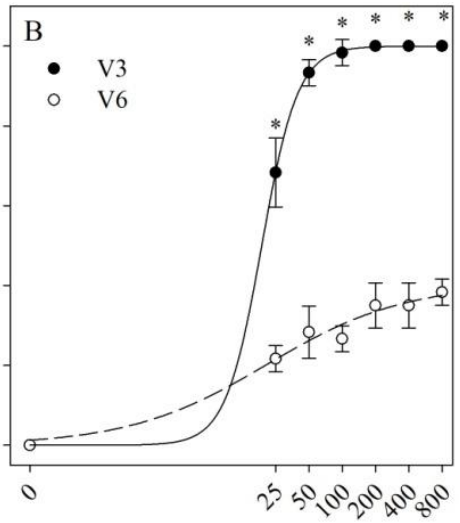

Quizalofop (mL C.P. ha $\left.{ }^{-1}\right)$

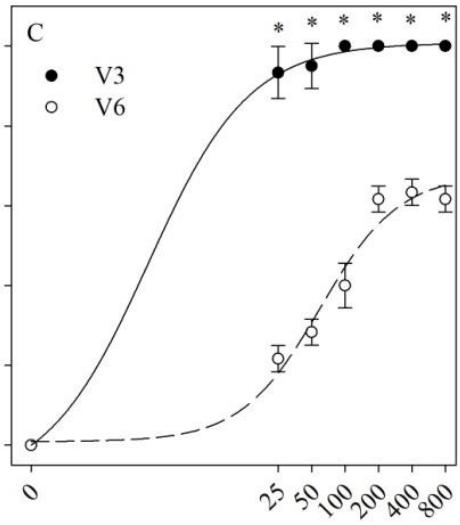

Clethodim + quizalofop ( $\mathrm{mL}$ C.P. ha $\left.^{-1}\right)$ 
Table 1. Parameters of the Log-logistic equation, correlation coefficient $\left(R^{2}\right)$, estimated $C_{50}$ and $G R_{50}$, and tolerance factor (TF) of volunteer RR corn according to the phenological stage (V3 or V6) of ACCase inhibitors application.

\begin{tabular}{|c|c|c|c|c|c|c|c|}
\hline \multirow{2}{*}{ Herbicide } & \multirow{2}{*}{ Stage } & a & $\mathrm{b}$ & $\mathrm{x}_{0}$ & $\mathrm{R}^{2}$ & $\mathrm{C}_{50}$ & TF \\
\hline & & \multicolumn{6}{|c|}{14 DAT } \\
\hline Clethodim & V3 & 101.43 & -1.68 & 22.18 & 0.99 & 21.81 & \multirow{2}{*}{$>36.68$} \\
\hline Clethodim & V6 & 44.93 & -0.83 & 79.49 & 0.99 & $>800.00$ & \\
\hline Quizalofop & V3 & 99.95 & -2.67 & 18.72 & 1.00 & 18.73 & \multirow{2}{*}{$>42.73$} \\
\hline Quizalofop & V6 & 40.50 & -0.69 & 20.93 & 0.97 & $>800.00$ & \\
\hline Clethodim + Quizalofop & V3 & 100.78 & -0.95 & 1.68 & 0.99 & 1.65 & \multirow{2}{*}{91.89} \\
\hline \multirow[t]{2}{*}{ Clethodim + Quizalofop } & V6 & 66.03 & -1.22 & 59.78 & 0.97 & 151.88 & \\
\hline & & \multicolumn{6}{|c|}{$21 \mathrm{DAT}$} \\
\hline Clethodim & V3 & 100.78 & -1.77 & 13.78 & 0.99 & 13.66 & \multirow{2}{*}{7.01} \\
\hline Clethodim & V6 & 100.92 & -0.61 & 98.71 & 0.99 & 95.80 & \\
\hline Quizalofop & V3 & 100.21 & -1.30 & 2.23 & 0.99 & 2.22 & \multirow{2}{*}{13.49} \\
\hline Quizalofop & V6 & 106.42 & -1.03 & 33.72 & 0.99 & 29.99 & \\
\hline Clethodim + Quizalofop & V3 & 99.36 & -1.67 & 3.02 & 0.99 & 3.04 & \multirow{2}{*}{$2.7 €$} \\
\hline \multirow[t]{2}{*}{ Clethodim + Quizalofop } & V6 & 102.13 & -0.98 & 8.63 & 0.99 & 8.39 & \\
\hline & & \multicolumn{6}{|c|}{28 DAT } \\
\hline Clethodim & V3 & 100.57 & -1.27 & 0.81 & 1.00 & 0.81 & \multirow{2}{*}{31.42} \\
\hline Clethodim & V6 & 101.05 & -1.48 & 25.79 & 0.99 & 25.43 & \\
\hline Quizalofop & V3 & 100.10 & -1.27 & 0.80 & 1.00 & 0.79 & \multirow{2}{*}{6.86} \\
\hline Quizalofop & V6 & 100.11 & -1.40 & 5.45 & 0.99 & 5.44 & \\
\hline Clethodim + Quizalofop & V3 & 100.11 & -1.28 & 0.80 & 1.00 & 0.80 & \multirow{2}{*}{1.62} \\
\hline Clethodim + Quizalofop & V6 & 100.68 & -0.88 & 1.31 & 1.00 & 1.29 & \\
\hline
\end{tabular}

a: maximum value of $y$; $b$ : slope of the curve at $x_{0} ; x_{0}$ : herbicide rate (in $\mathrm{mL} \mathrm{C.P.} \mathrm{ha}{ }^{-1}$ ) that causes $50 \%$ of the maximum control observed; $C_{50}$ : estimated herbicide rate (in $\mathrm{mL} \mathrm{C.P.}^{-1}{ }^{-1}$ ) that causes $50 \%$ control; TF: tolerance factor obtained by dividing the $\mathrm{C}_{50}$ at $\mathrm{V} 6$ by their respective values at $\mathrm{V} 3$.

At 21 DAT, control increased for all herbicides and application stages (Figure 2) compared to the previous evaluation. As well as for 14 DAT, the application at V3 stage resulted in better controls than the application at V6. For the herbicide clethodim, the control was $100 \%$ with $100 \mathrm{~mL}$ C.P. ha ${ }^{-1}$ applied at V3. However, control was only $60 \%$ when the same rate was applied at V6 plants (Figure 2A). These results can be confirmed by the $C_{50}$ values, which were 13.66 $\mathrm{mL}$ C.P. ha ${ }^{-1}$ for application at $\mathrm{V} 3$ and $95.80 \mathrm{~mL}$ C.P. ha $^{-1}$ for application at $\mathrm{V} 6$, resulting in a tolerance factor 7.01 higher for application at V6 (Table 1).

For quizalofop-P-tefuryl, the control at 21 DAT was superior in both stages of application reaching $100 \%$ in rates equal to or greater than $400 \mathrm{~mL}$ C.P. ha $^{-1}$. Similar control was obtained with $25 \%$ of this rate $\left(100 \mathrm{~mL}\right.$ C.P. ha $\left.{ }^{-1}\right)$ when the application was carried out at V3 (Figure 2B). The $\mathrm{C}_{50}$ values were $2.22 \mathrm{~mL} \mathrm{C.P.} \mathrm{ha-1} \mathrm{for} \mathrm{application}$ at V3 and $29.99 \mathrm{~mL}$ C.P. ha ${ }^{-1}$ for application at V6, resulting in tolerance factor of 13.49 (Table 1 ).

For the mixture of clethodim + quizalofop$P$-ethyl $100 \%$ control was achieved at 21 DAT for $200 \mathrm{~mL} \mathrm{C.P.} \mathrm{ha}{ }^{-1}$, regardless of the stage of application (Figure 2C). For lower rates, control at V3 as well as for the other herbicides was superior in comparison to the application at V6. For application at V3 the $\mathrm{C}_{50}$ obtained was 3.04 $\mathrm{mL} \mathrm{C.P.} \mathrm{ha}{ }^{-1}$, whereas for application at V6 this value was 2.76 -fold higher ( $8.39 \mathrm{~mL}$ C.P. ha $^{-1}$ ) (Table 1). 
Figure 2. Control of volunteer RR corn at 21 DAT in response to the application of rates of clethodim (A), quizalofop-P-tefuryl (B) and clethodim + quizalofop-P-ethyl (C) at V3 and V6 stages. * indicates significance by the Tukey test $(p<0.05)$ between stages within the same herbicide rate.

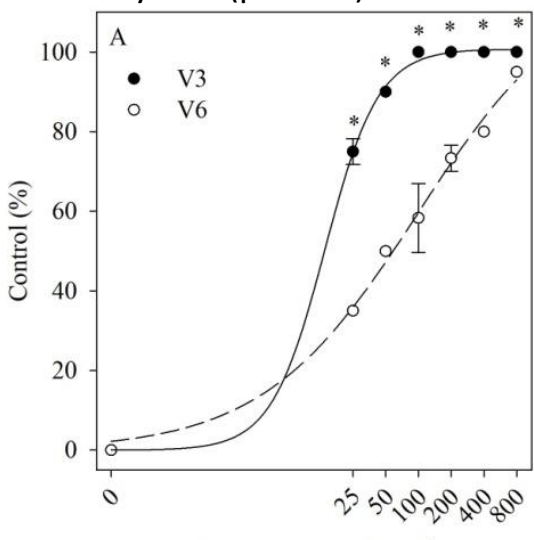

Clethodim (mL C.P. ha $\left.{ }^{-1}\right)$

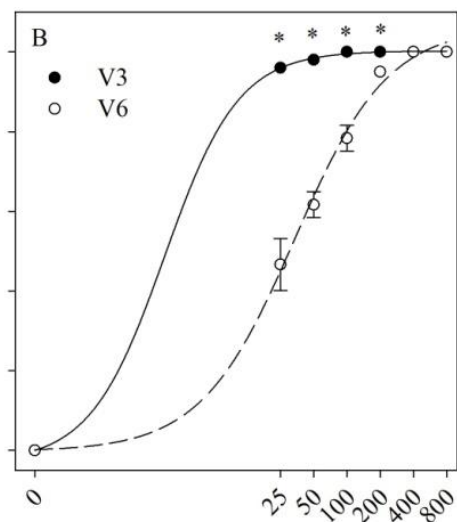

Quizalofop (mL C.P. ha $\left.{ }^{-1}\right)$

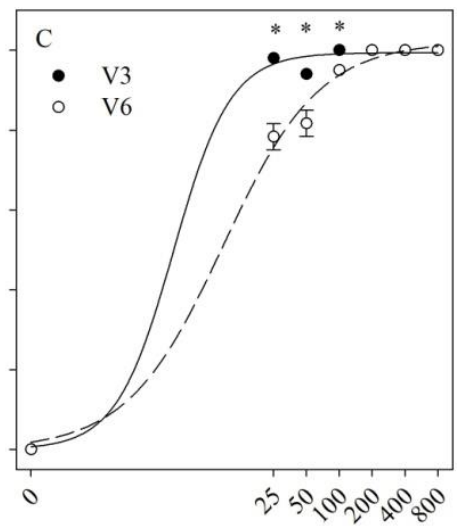

Clethodim + quizalofop $\left(\mathrm{mL}\right.$ C.P. $\left.\mathrm{ha}^{-1}\right)$
In the final evaluation performed at 28 DAT, applications at V3 stage were more efficient compared to those in $\mathrm{V} 6$ for clethodim rates equal to or less than $200 \mathrm{~mL}$ C.P. ha ${ }^{-1}$ (Figure 3A). At V3 stage, all tested rates had $100 \%$ volunteer corn control (Figures $3 \mathrm{~A}$ and $4 \mathrm{~A}$ ). However, control at $\mathrm{V} 6$ reached $100 \%$ only at rates starting from $400 \mathrm{~mL}$ C.P. ha ${ }^{-1}$ (Figures $3 \mathrm{~A}$ and $4 \mathrm{~B}$ ). The
$400 \mathrm{~mL}$ C.P. ha ${ }^{-1}$ rate had $100 \%$ volunteer corn control regardless of the phenological stage at the time of application. At V6, $\mathrm{C}_{50}$ was equivalent to $25.43 \mathrm{~mL}$ C.P. ha ${ }^{-1}$, approximately 31 -fold greater than that obtained in the applications at V3 (Table 1).

Figure 3. Control of volunteer RR corn at 28 DAT in response to the application of rates of clethodim (A), quizalofop-P-tefuryl (B) and clethodim + quizalofop-P-ethyl (C) at V3 and V6 stages. ${ }^{*}$ indicates significance by the Tukey test $(p<0.05)$ between stages within the same herbicide rate.

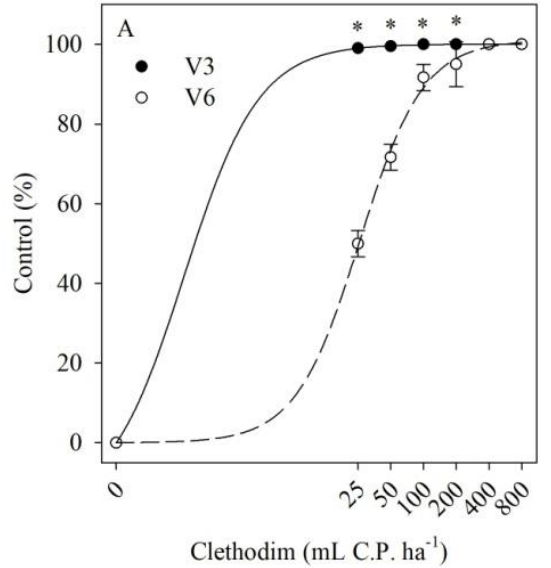

Clethodim (mL C.P. ha $\left.{ }^{-1}\right)$

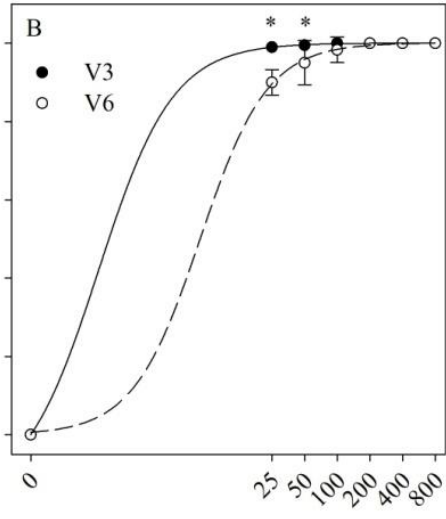

Quizalofop (mL C.P. ha $\left.{ }^{-1}\right)$

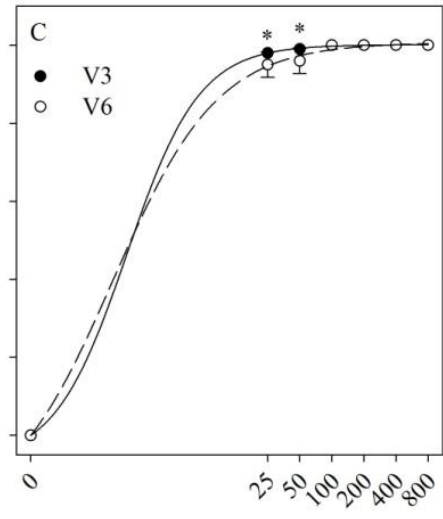

Clethodim + quizalofop $\left(\mathrm{mL}\right.$ C.P. ha $\left.^{-1}\right)$ 
Figure 4. Control of volunteer RR corn at 28 DAT in response to rates of clethodim applied at V3 (A) and V6 (B), quizalofop-P-tefuryl applied at V3 (C) and V6 (D), and clethodim + quizalofop-P-ethyl applied at V3 (E) and V6 (F).
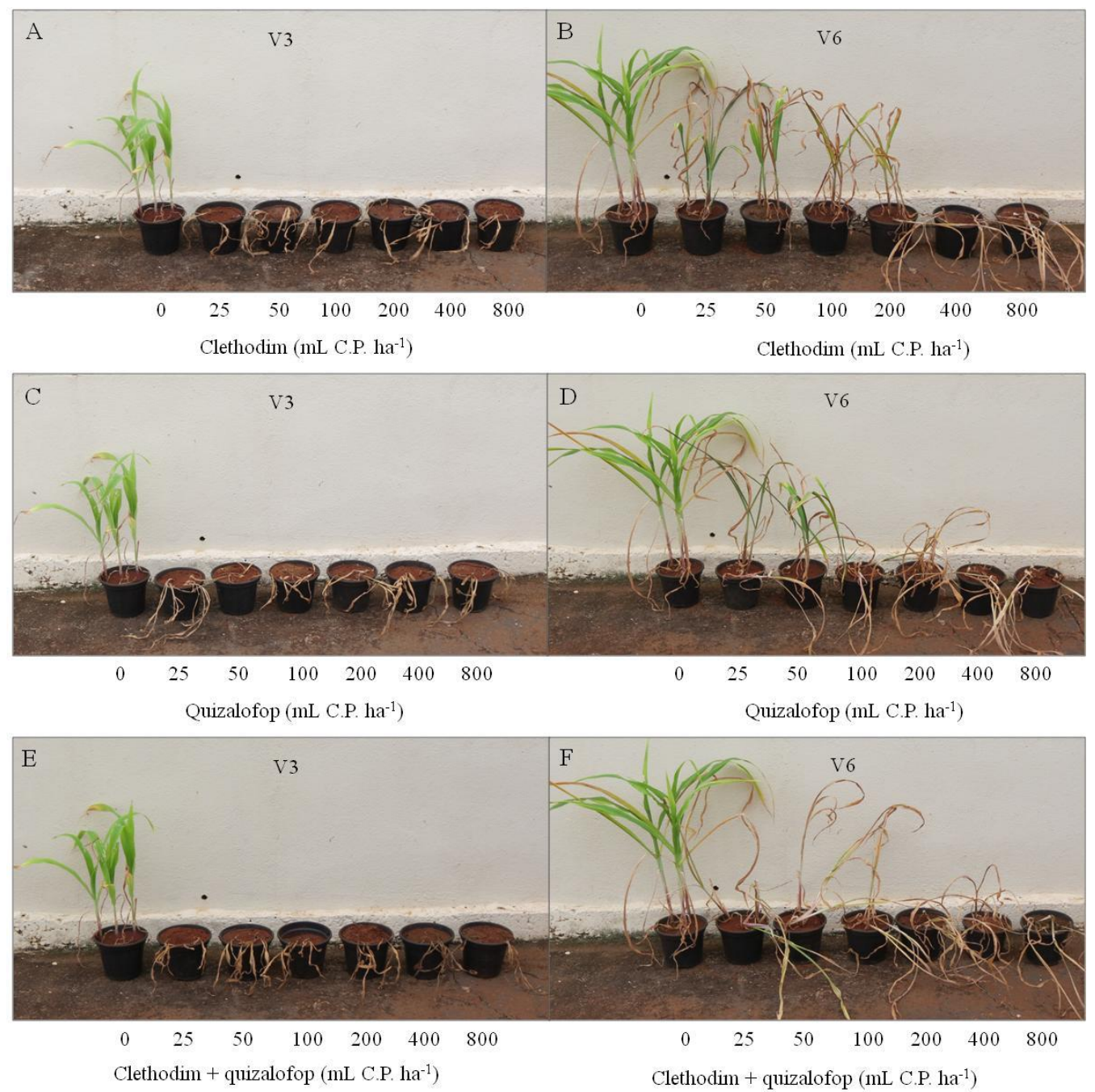

For the herbicides quizalofop- $P$-tefuryl (Figure 3B) and clethodim + quizalofop-P-ethyl (Figure $3 \mathrm{C}$ ), the control was superior at V3 only for the lowest rates of the herbicides, equivalent to 25 and $50 \mathrm{~mL} \mathrm{C.P.} \mathrm{ha}{ }^{-1}$. At V3, control was total for both herbicides and rates. However, at V6 stage, the control was total from $100 \mathrm{~mL}$ C.P. ha ${ }^{-1}$, as can be seen in figure 4 . It is observed, therefore, that clethodim was the herbicide most responsive to the application stage, followed by quizalofop- $P$-tefuryl and clethodim + quizalofop$P$-ethyl, with tolerance factors of $31.42 ; 6.86$ and 1.62, respectively (Table 1 ).

The results of shoot dry mass (SDM) (Figure 5) confirm the control observed at 28 DAT. As expected, the SDM was higher in V6 for all herbicides and rates evaluated. For clethodim (Figure $5 \mathrm{~A}$ ), the $\mathrm{GR}_{50}$ for application at V3 was $11.09 \mathrm{~mL}$ C.P. ha ${ }^{-1}$, whereas for application at V6

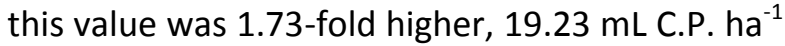
(Table 2). For quizalofop- $P$-tefuryl (Figure $5 \mathrm{~B}$ ), the

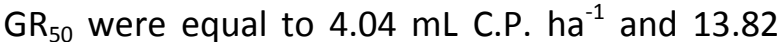
$\mathrm{mL}$ C.P. $\mathrm{ha}^{-1}$ for stages $\mathrm{V} 3$ and $V 6$, respectively, resulting in a tolerance factor of 3.42. For the mixture of clethodim + quizalofop- $P$-ethyl (Figure $5 C$ ), the $\mathrm{GR}_{50}$ for application at $\mathrm{V} 3$ was $3.36 \mathrm{~mL}$ C.P. ha $^{-1}$ for application at $\mathrm{V} 3$, and $4.99 \mathrm{~mL}$ C.P. $\mathrm{ha}^{-1}$ for application at $\mathrm{V} 6$, resulting in a tolerance factor of 1.48 (Table 2). 
Figure 5. Shoot dry mass (SDM) relative of volunteer RR corn in response to the application of rates of clethodim (A), quizalofop-P-tefuryl (B) and clethodim + quizalofop-P-ethyl (C) at V3 and V6 stages. * indicates significance by the Tukey test $(p<0.05)$ between stages within the same herbicide rate.

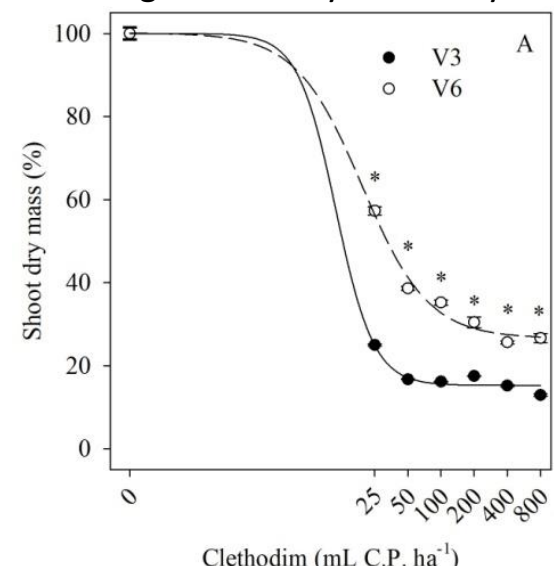

Clethodim (mL C.P. ha $\left.{ }^{-1}\right)$

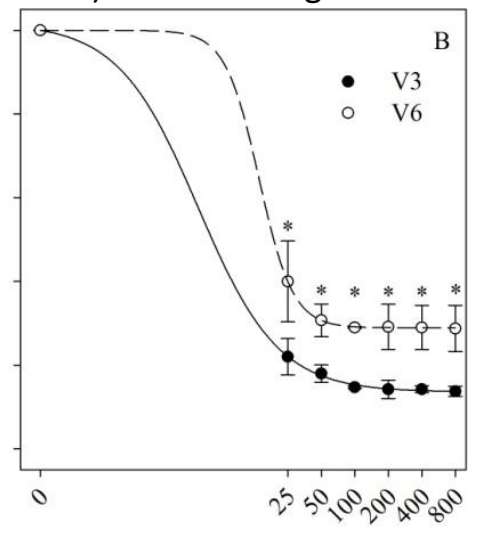

Quizalofop (mL C.P. ha ${ }^{-1}$ )

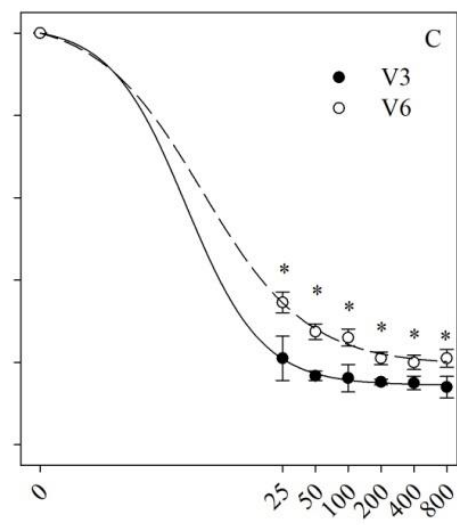

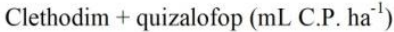

Table 2. Parameters of the Log-logistic equation, correlation coefficient $\left(R^{2}\right)$, estimated $G R_{50}$, and tolerance factor (TF) of volunteer RR corn according to the phenological stage (V3 or V6) of ACCase inhibitors application.

\begin{tabular}{lcccrcrr}
\hline Herbicide & Stage & $\mathrm{a}$ & $\mathrm{b}$ & \multicolumn{1}{c}{$\mathrm{x}_{0}$} & $\mathrm{R}^{2}$ & $\mathrm{GR}_{50}$ & $\mathrm{TF}$ \\
\hline Clethodim & $\mathrm{V} 3$ & 100.00 & 2.52 & 11.09 & 0.99 & 11.09 & 1.73 \\
Clethodim & $\mathrm{V} 6$ & 100.11 & 1.45 & 19.20 & 0.99 & 19.23 & \\
\hline Quizalofop & $\mathrm{V} 3$ & 101.66 & 1.20 & 3.93 & 1.00 & 4.04 & 3.42 \\
Quizalofop & V6 & 100.00 & 2.85 & 13.82 & 1.00 & 13.82 & \\
\hline Clethodim + Quizalofop & V3 & 101.82 & 1.25 & 3.27 & 1.00 & 3.36 & 1.48 \\
Clethodim + Quizalofop & V6 & 103.67 & 0.90 & 4.61 & 0.99 & 4.99 & \\
\hline
\end{tabular}

a: maximum value of $y$; $b$ : slope of the curve at $\mathrm{x}_{0} ; \mathrm{x}_{0}$ : herbicide rate (in $\mathrm{mL}$ C.P. ha ${ }^{-1}$ ) that causes $50 \%$ of reduction in shoot dry mass; $\mathrm{GR}_{50}$ : estimated herbicide rate (in $\mathrm{mL}$ C.P. ha ${ }^{-1}$ ) that causes $50 \%$ of reduction in shoot dry mass; TF: tolerance factor obtained by dividing the $\mathrm{GR}_{50}$ at $\mathrm{V} 6$ by their respective values at $\mathrm{V} 3$.

In general, the application of the evaluated graminicides resulted in better control when performed on corn at V3 stage compared to applications at V6. In addition, it was observed that clethodim efficacy was more influenced by the corn phenological stage than quizalofop- $P$ tefuryl and clethodim + quizalofop- $P$-ethyl (Figures 3, 4, and Table 1). Generally, late applications of graminicides, mainly DIMs, result in less control of volunteer corn. The herbicide clethodim had its efficiency reduced from 99\% when applied to corn at stage $\mathrm{V} 3$ to $88 \%$ when applied at V6 (CHAHAL; JHALA, 2015). However, the same authors observed that for the herbicide quizalofop- $P$-ethyl, the efficiency was less impaired with the advance in the application stage, going from $99 \%$ to $97 \%$. Similarly, Pertile et al. (2018) observed that haloxyfop-P-methyl efficiency was $100 \%$ when the herbicide was applied at V2-V3, and reduced to $98 \%$ when performed at V6-V8. However, the same authors observed that for clethodim control efficiency was reduced from $100 \%$ to just $23 \%$ with the delay in the application.

The higher sensitivity of volunteer corn to graminicides when applied to plants in early stages of development (Figures 3, 4, and Table 1) is justified by some factors, such as less wax in the cuticle, which facilitates the absorption of herbicides (BLAKER; GREYSON, 1988). In contrast, plants at stages from V6, in addition to having a higher content of waxes and thicker cuticle, have greater lignification of cell walls, which can result in less absorption of herbicides (MARQUARDT; JOHNSON, 2013). In addition to these factors, the activity of the ACCase enzyme is greater in young tissues, in which the demand for lipids is greater due to the growth of the expanding leaves 
(MOTEL et al., 1993). Also, in taller plants, the distance between the absorption points and the meristems of the corn plants is greater, requiring greater translocation of the herbicides for an effective control. Finally, although at low levels, older plants have higher herbicide metabolism activity, making them more tolerant (CARVALHO et al., 2009).

The greater effectiveness of the quizalofop- $P$ in late applications (Figures 3, 4, and Table 1 ) is due in part to its greater affinity with the cuticle compared to the herbicide clethodim. In general, FOPs have greater affinity with the cuticle, since they have higher octanol/water partition coefficient (log kow) compared to clethodim (COBB; READE, 2010). For quizalofop$P$, the Log Kow is 4.66, while for clethodim, it is 1.6 (SHANER, 2014). In addition, quizalofop- $P$ has a greater inhibitory capacity for the enzyme ACCase compared to clethodim (BURTON et al., 1989). According to the authors, in a solution containing $1 \mu \mathrm{M}$ of quizalofop ACCase inhibition reaches 97\%, whereas for clethodim the inhibition is only $60 \%$. For these reasons, the control of volunteer corn was lower with the isolated application of clethodim, especially when applied at V6 (Figures 3, 4, and Table 1).

Although volunteer corn control was satisfactory in early growth stages for all the herbicides tested (Figure 3), the occurrence of several volunteer corn emergence flows from ears or pieces of ears (clumps) poses a challenge for herbicide application timing. It is economically unfeasible and technically not recommended to conduct repeated applications of ACCase inhibitors since these herbicides have no residual effect (LANCASTER et al., 2018). However, when the plants come only from threshed and lost grains after harvest, the emergence occurs right after the first rains, making it possible to control in stages close to those with greater sensitivity to graminicides (SILVA et al., 2018). An alternative is the use of pre-emergents in soybean crops, such as imazapic + imazapyr, diclosulam, chlorimuron + sulfometuron. Although these herbicides do not control clumps by $100 \%$, these applications can reduce the development of corn plants and favor post-emergent control with ACCase inhibitors (PIASECKI; RIZZARDI, 2016).

In general, quizalofop- $P$-tefuryl and the mixture of clethodim + quizalofop- $P$-ethyl showed the best results and were less influenced by corn phenological stage during applications
(Figures 3, 4, and Table 1). These results corroborate previous research reporting that FOPs were more efficient than DIMS in controlling volunteer corn even at later growth stages (COSTA et al., 2014). However, genetically modified corn hybrids with the insertion of the aad-1 gene are being developed to confer tolerance to FOPs (NANDULA, 2019). Therefore, the control of volunteer corn from these hybrids should be carried out with other herbicides, mainly by DIMs. In addition to the lower efficiency of clethodim for the control of volunteer corn, the continued use of this herbicide may lead to the selection of resistant weeds (POWLES; YU, 2010). Although they belong to the same site of action, the binding of FOPs and DIMs to the catalytic site of the ACCase enzyme shares only a few amino acids (LIU et al., 2007). Thus, resistance is not always crossed, that is, plants resistant to FOPs can be controlled by DIMs and vice versa, depending on the mechanism of resistance. An example of this is the resistance of sourgrass (Digitaria insularis) to FOPs due to the Trp2027Cys mutation, which does not confer resistance to DIMs (TAKANO et al., 2020).

In this work, commercial rates of each product were considered since both herbicides are recommended in the same rate range of commercial product for the control of volunteer corn (AGROFIT, 2020). However, as described in the material and methods section, the concentration of active ingredients in these products is not proportional. The mixture of clethodim + quizalofop- $P$-ethyl used in this experiment contains the same concentration of each active ingredient in their respective commercial products. Even so, the control provided by the mixture was very similar to the isolated application of quizalofop- $P$-tefuryl. This can be explained by the fact that the binding of a FOP or DIM herbicide to the ACCase enzyme action site shares some amino acids, making it impossible for a quizalofop- $P$ molecule and a clethodim molecule to bind at the same time (LIU et al., 2007).

\section{Conclusion}

The control of volunteer RR corn with ACCase inhibitors was more efficient when performed in early phenological stage (V3) compared to the late stage (V6). The herbicide quizalofop-P-tefuryl was more effective than 
clethodim isolated. When combined, clethodim + quizalofop-P-ethyl achieved control close to $100 \%$ at both V3 and V6 stages. The efficiency of clethodim is highly influenced by the volunteer corn growth stage. At V3, 100\% control was achieved with a rate of $25 \mathrm{~mL} \mathrm{C.P.} \mathrm{ha}^{-1}$ (equivalent to $6 \mathrm{~g}$ a.i. ha ${ }^{-1}$ ), while for application at V6 were necessary $400 \mathrm{~mL} \mathrm{C.P.} \mathrm{ha}{ }^{-1}$ (equivalent to $96 \mathrm{~g}$ a.i. $\mathrm{ha}^{-1}$ ) for complete control. However, only $100 \mathrm{~mL}$ C.P. ha ${ }^{-1}$ of quizalofop-P-tefuryl (equivalent to 12 g a.i. ha ${ }^{-1}$ ) and $100 \mathrm{~mL} \mathrm{C.P.} \mathrm{ha}{ }^{-1}$ of clethodim + quizalofop-P-ethyl (equivalent to $24+12 \mathrm{~g}$ a.i. ha $\left.{ }^{1}\right)$ were necessary to achieve $100 \%$ of plant mortality at $\mathrm{V} 6$ stage.

\section{References}

ALBRECHT, A. J. P.; ALBRECHT, L. P.; BARROSO, A. A.; VICTÓRIA FILHO, R. O milho RR2 e o glyphosate: uma revisão. Revista Brasileira de Herbicidas, v.13, n.1, p.58-67, 2014. https://doi.org/10.7824/rbh.v13i1.279

BLAKER, T. W.; GREYSON, R. I. Developmental variation of leaf surface wax of maize, Zea mays. Canadian Journal of Botany, v.66, n.5, p.839-846, 1988. https://doi.org/10.1139/b88-122

AGROFIT. Consulta de ingrediente ativo. Disponível em: http://agrofit.agricultura.gov.br/agrofit_cons/pri ncipal_agrofit_cons. Acesso em: 31 abr. 2020.

BURTON, J. D.; GRONWALD, J. W.; SOMERS, D. A.; GENGEBACH, B. G.; WYSE, D. L. Inhibition of corn acetyl-CoA carboxylase by cyclohexanedione and aryloxyphenoxypropionate herbicides. Pesticide Biochemistry and Physiology, v.34, n.1, p.76-85, $1989 . \quad$ https://doi.org/10.1016/00483575(89)90143-0

CARVALHO, S. J. P.; NICOLAI, M.; FERREIRA, R. R.; FIGUEIRA, A. V. O.; CHRISTOFFOLETI, P. J. Herbicide selectivity by differential metabolism: considerations for reducing crop damages. Scientia Agricola, v.66, n.1, p.136-142, 2009. https://doi.org/10.1590/S0103$\underline{90162009000100020}$

CARVALHO, S. J. P.; UZUELE, E. L.; SOARES, D. J.; LÓPEZ-OVEJERO, R. F.; CHRISTOFFOLETI, P. J. Control of glyphosate-resistant volunteer maize using ACCase inhibiting herbicides. Revista Caatinga, v.32, n.3, p.575-580, 2019. https://doi.org/10.1590/1983-

\section{9v32n301rc}

CHAHAL, P. S.; JHALA, A. J. Herbicide programs for control of glyphosate-resistant volunteer corn in glufosinate-resistant soybean. Weed Technology, v.29, n.3, p.431-443, 2015. https://doi.org/10.1614/WT-D-15-00001.1

COBB, A. H.; READE, J. P. H. Herbicides and Plant Physiology. 2. ed. Newport: Wiley-Blackwell, 2010. 286 p.

COSTA, N. V.; ZOBIOLE, L. H. S.; SCARIOT, C. A.; PEREIRA, G. R.; MORATELLI, G. Glyphosate tolerant volunteer corn control at two development stages. Planta Daninha, v.32, n.4, p.675-682, 2014. https://doi.org/10.1590/S0100$\underline{83582014000400002}$

FANCELLI, A. L.; DOURADO-NETO, D. Fenologia do milho. In: FANCELLI, A. L.; DOURADO-NETO, D. (Coords.). Tecnologia da produção de milho. Piracicaba: Publique, 1997. p. 131-140.

LANCASTER, Z. D.; NORSWORTHY, J. K.; SCOTT, R. C. Residual activity of ACCase-inhibiting herbicides on monocot crops and weeds. Weed Technology, v.32, n.4, p.364-370, 2018. https://doi.org/10.1017/wet.2018.13

LIU, W.; HARRISON, D. K.; CHALUPSKA, D.; GORNICKI, P.; O'DONNELL, C.C.; ADKINS, S. W.; HASELKORN, R.; WILLIAMS, R. R. Single-site mutations in the carboxyltransferase domain of plastid acetyl-CoA carboxylase confer resistance to grass-specific herbicides. Proceedings of the National Academy, v.104, n.9, p.3627-3632, 2007. https://doi.org/10.1073/pnas.0611572104

LÓPEZ-OVEJERO, R. F.; SOARES, D. J.; OLIVEIRA, N. C.; KAWAGUCHI, I. T.; BERGER, G. U.; CARVALHO, S. J. P.; CHRISTOFFOLETI, P. J. Interferência e controle de milho voluntário tolerante ao glifosato na cultura da soja. Pesquisa Agropecuária Brasileira, v.51, n.4, p.340-347, 2016. http://dx.doi.org/10.1590/S0100$\underline{204 \times 2016000400006}$

MACIEL, C. D. G; ZOBIOLE. L. H. S.; SOUZA, J. I.; HIROOKA, E.; LUCAS GEANINY NORO VARGAS DE LIMA, L. G. N. V.; SOARES, C. R. B.; PIVATTO, R. A. D.; FUCHS, G. M.; HELVIG, E. O. Eficácia do herbicida haloxyfop $R$ (GR-142) isolado e 
associado ao 2,4-D no controle de híbridos de milho $\mathrm{RR}^{\circ}$ voluntário. Revista Brasileira de Herbicidas, v.12, n.2, p.112-123, 2013. https://doi.org/10.7824/rbh.v12i2.244

MARCA, V.; PROCÓPIO, S. O.; SILVA, A. G.; VOLF, $M$. Controle químico de milho voluntário resistente ao herbicida glyphosate. Revista Brasileira de Herbicidas, v.14, n.2, p.103-110, 2015. https://doi.org/10.7824/rbh.v14i2.408

MARQUARDT, P. T.; JOHNSON, W. G. Influence of clethodim application timing on control of volunteer maize in soybean. Weed Technology, v.27, n.4, p.645-648, 2013. https://doi.org/10.1614/WT-D-12-00188.1

MOTEL, A.; GÜNTHER, S.; CLAUSS, M.; KOBEK, K.; FOCKE, M.; LICHTENTHALER, H. K. Studies on the inhibition of biotin-containing carboxylases by acetyl-coa carboxylase inhibitors. Zeitschrift für Naturforschung C, v.48, n.3-4, p.294-300, 1993. https://doi.org/10.1515/znc-1993-3-429

NANDULA, V. K. Herbicide resistance traits in maize and soybean: current status and future outlook. Plants, v.8, n.9, p.337-345, 2019. https://doi.org/10.3390/plants8090337

PERTILE, M.; CECHIN, J.; ZIMMER, V.; AGOSTINETTO, D.; VARGAS, L. Interference of volunteer corn in glyphosate resistant soybean and chemical control in different phenological stages. Bioscience Journal, v.34, n.5, p.12481257, 2018. https://doi.org/10.14393/BJv34n5a2018-39462

PIASECKI, C.; RIZZARDI, M. A. Herbicidas aplicados em pré-emergência controlam plantas individuais e touceiras de milho voluntário $R^{\circ}{ }^{\circ} \mathrm{F} 2$ em soja? Revista Brasileira de Herbicidas, v.15, n.4, p.332-340, 2016. https://doi.org/10.7824/rbh.v15i4.497

PIASECKI, C.; RIZZARDI, M. A.; SCHWADE, D. P.; TRES, M.; SARTORI, J. Interference of $\mathrm{GR}^{\circ}$ volunteer corn population and origin on soybean grain yield losses. Planta Daninha, v.36, e018161420, 2018.

http://dx.doi.org/10.1590/s0100-

83582018360100003
POWLES, S. B.; YU, Q. Evolution in action: plants resistant to herbicides. Annual Review of Plant Biology, v.61, n.1. p.317-347, 2010. https://doi.org/10.1146/annurev-arplant042809-112119

R CORE TEAM. R: A language and environment for statistical computing. Vienna, Austria: R Foundation for Statistical Computing, 2019. https://www.R-project.org/

RITZ, C.; KNISS, A. R.; STREIBIG, J. C. Research methods in weed science: statistics. Weed Science, v.63, n.sp, p.166-187, 2015. https://doi.org/10.1614/WS-D-13-00159.1

SAGE, R. F. The evolution of C4 photosynthesis. New Phytologist, v.161, n.2, p.341-370, 2004. https://doi.org/10.1111/j.14698137.2004.00974.x

SHANER, D. L. Herbicide Handbook. 10. ed. Lawrence: Weed Science Society of America, 2014. $513 \mathrm{p}$.

SILVA, A. F.; ADEGAS, F. S.; CONCENÇO, G. Characterization of emergence flows of volunteer corn as function of the type of harvest grain loss. Journal of Agricultural Science, v.10, n.5, p.258267, 2018. https://doi.org/10.5539/jas.v10n5p258

SILVA, A. F.; FERREIRA, E. A.; CONCENÇO, G.; FERREIRA, F. A.; ASPIAZU, I.; GALON, L.; SEDIYAMA, T.; SILVA, A. A. Densidades de plantas daninhas e épocas de controle sobre os componentes de produção da soja. Planta Daninha, v.26, n.1, p.65-71, 2008. https://doi.org/10.1590/S0100$\underline{83582008000100007}$

TABILE, R. A.; TOLEDO, A.; SILVA, R. P.; FURLANI, C. E. A.; CORTEZ, J. W.; GROTTA, D. C. C. Perdas na colheita de milho em função da rotação do cilindro trilhador e umidade dos grãos. Scientia Agraria, v.9, n.4, p.505-510, 2008. http://dx.doi.org/10.5380/rsa.v9i4.11709

TAKANO, H. K.; MELO, M. S. C.; OVEJERO, R. F. L.; WESTRA, P. H.; GAINES; T. A.; DAYAN, F. E. Trp2027Cys mutation evolves in Digitaria insularis with cross-resistance to ACCase inhibitors. Pesticide Biochemistry and 
Physiology, v.164, n.1, p.1-6, 2020.

https://doi.org/10.1016/j.pestbp.2019.12.011 